The list of materials of the registration dossier and the formation approved by the state Committee of veterinary medicine. Retrieved from http://www.biocontrol.com.ua/.

23. Code of Federal Regulations, SAM 200 Supplemental Assay Method Potency Testing Products Containing Clostridium chauvoei Antigen 9CFR 113.106. U.S. Government Printing Office, Washington. Retrieved from http://www.rspca.org.uk/servlet/.

\title{
УДК: 639:615.9:636.085
}

ВАСЯНОВИЧ О.М., канд. с.-г. наук, ст.наук. сп., e-mail:myco-ivm@ rambler.ru, РУДА М.Є., канд. вет. наук, ст.наук. сп., е-mail:rudayamargo@gmail.com, ЯНГОЛЬ Ю.А.*, e-mail:juliajangol@gmail.com Інститут ветеринарної медициини НАAH

\section{ВСТАНОВЛЕННЯ ВИДОВОЇ ПРИНАЛЕЖНОСТІ МІКРОМІЦЕТІВ ТА ВИВЧЕННЯ ЇХ ЗДАТНОСТІ ПРОДУКУВАТИ ФУЗАРІОТОКСИНИ}

Проведено мікотоксикологічні дослідження 35 зразків зернових та комбінованих кормів, з яких ізольовано та ідентифіковано до виду 78 штамів мікроміцетів. Встановлено, що найбільш розповсюдженими були гриби роду Fusarium - 26,9\% від загальної кількості досліджених проб, Penicillium - 18,0, Aspergillus - 20,5 \%. Дослідженнями на тест-об'єкті Tetrachimena pyriformis встановлено токсичну дію y 40 штамів із 78 досліджених. В результаті вивчення токсигенного потенціалу найбільш розповсюджених мікроміцетів грибів роду Fusarium було виділено 7 продуцентів T-2 токсину, 9 продущеетів - зеараленону та 11 - фумонізинів від 27 досліджених токсичних штамів. фумонізини.

Ключові слова: мікроміџети, зерно, мікологічні дослідження, фузаріотоксини,

Вступ. Серед багатьох токсичних факторів зовнішнього середовища все більше уваги привертають саме метаболіти плісеневих грибів - мікотоксини. Вже давно встановлено понад 150 видів плісеневих грибів, які продукують майже 300 мікотоксинів різних за своїми токсичними властивостями та хімічною будовою.

Лише трихотеценових мікотоксинів виділено та вивчено понад 45. Вони $\epsilon$ природними контамінантами кормів та продуктів харчування. Серед них особливо високою токсичністю та частотою виявлення виділяється Т-2 токсин, який $\epsilon$ головним етіологічним фактором фузаріотоксикозів сільськогосподарських тварин $[1,2]$. Фузаріотоксикоз періодично реєструють як в нашій країні так і за кордоном. Він протікає гостро, підгостро, хронічно, призводить до загибелі тварин, зниження їх продуктивності, імунної відповіді.

Ще один із мікотоксинів, який останніми роками внаслідок глобального потепління набув широкого розповсюдження в країнах СС та СНГ - фумонізин $\mathrm{B}_{1}$. Цей мікотоксин викликає лейкоенцефаломаляцію у коней або набряк легень у свиней. Фумонізин В 1 є токсичним як для печінки, нирок, так і для серцевосудинної системи усіх видів тварин, викликає патологію мітозу в уражених

\footnotetext{
* Аспірант, науковий керівник - канд. с.-г. наук Васянович О.М.
} 
тканинах 3 подальшою загибеллю клітин. Ці фумонізини порушують метаболізм сфінголіпідів, якими насичена нервова тканина і які захищають клітинні мембрани від негативних впливів. Також вони $є$ причиною блокування механізму переносу глюкози за рахунок інгібування ферменту глюкоцерамідсинтази [3].

Забруднення зерна мікотоксинами можливе на всіх етапах його виробництва, транспортування, зберігання, переробки і використання і є одним iз факторів, що впливає на продуктивність сільськогосподарських тварин i птиці, якість і медико-біологічну відповідність продуктів харчування тваринного походження. В останні роки особливу увагу приділяють якості фуражного зерна. В кормовому балансі сільськогосподарських тварин, перш за все свиней і птиці, воно займає значну питому вагу як по масі, так і по вартості, тому і є пріоритетним об'єктом вивчення [4].

Повноцінна годівля тварин - важливий фактор, який визначає успішний розвиток тваринництва. Регуляція i оптимізація годівлі мають тісний органічний зв’язок 3 виробництвом кормів, технологією їх зберігання, переробки та використання.

Метою даної роботи було встановлення видової приналежності мікроміцетів у зернофуражі 3 різних областей України та вивчення розповсюдження мікроміцетів здатних до токсиноутворення фузаріотоксинів.

Матеріали та методи досліджень. В результаті проведеної роботи були відібрані зразки кормів (висівки, овес, ячмінь, соя, кукурудза, пшениця, кормосуміш, комбікорми) для дослідження на засміченість мікроміцетами, наявність мікотоксинів та на токсичність. Корми для досліджень надходили від приватних та орендних підприємств Київської, Миколаївської, Черкаської областей.

Після виділення грибів 3 відібраних зразків проводили ідентифікацію мікроміцетів до виду за допомогою мікроскопічних досліджень. Отримані дані порівнювали з даними визначників [5-9].

Також проводили роботи по вивченню токсичності штамів мікроміцетів по відношенню до тест-мікроорганізму Tetrachimena pyriformis шляхом дії їх культуральних рідин на тест-мікроорганізм. Підрахунки та оцінку результатів проводили через 30 хвилин, 1 годину, враховуючи при цьому ефект біопроби в краплі, взятій пастерівською піпеткою на предметному склі під мікроскопом (збільшення 7×10) шляхом проглядання всього об’єму краплі та всіх їі шарів. Токсичні штами викликали загибель Tetrachimena pyriformis протягом 30 хвилин, слаботоксичні - протягом 1 години. Нетоксичні штами, через 1 годину спостереження загибелі або будь-яких морфологічних змін у інфузоріях не викликали [10].

Токсичні та слаботоксичні види грибів досліджували на здатність їх до утворення мікотоксинів (токсиноутворення) за допомогою експрес-методу, розробленим в лабораторії. Кількісний вміст мікотоксинів в культурі визначали за «Скринінг-методом» [11].

При вивченні здатності грибів продукувати фумонізини використовували 
«Методику визначення фумонізинів $\mathrm{B}_{1}, \mathrm{~B}_{2}$ в кормах методом тонкошарової хроматографії». Для якісного визначення фумонізинів, на хроматографічну пластину «Сорбфіл» на відстані 1,5-2 см один від одного, від нижнього та бокових країв пластини, наносили розчин екстракту в кількості 2 мкл, 5, 10 та 15 мкл. Одночасно з досліджуваними пробами на пластину наносили 2 мкл, 5, 10 мкл стандартного розчину суміші мікотоксинів. Діаметр плям нанесених досліджуваних проб повинен відповідати діаметру плям стандартних проб.

Пластину поміщали в хроматографічну камеру i хроматографували в системі ацетонітрил - вода - оцтова кислота (50:50:1). Коли фронт розчинника піднімався на висоту 10-12 см від старту, пластини виймали і сушили при кімнатній температурі і обробляли декагідратом нітраборатом натрію разом 3 флуорескамінатом розчинним в ацетонітрилі. Через 1 хв пластину обробляли 0,1 М сумішшю борної кислоти та ацетонітрилу (40:60). Пластину підсушували на повітрі і розглядали в УФ променях, при довжині хвилі 3,55 нм. Фумонізини виявляли візуально порівнянням із стандартами $\mathrm{B}_{1}, \mathrm{~B}_{2} 3$ Rf 0,5 i 0,1 відповідно, що проявлялися яскравим жовто-зеленим кольором.

Результати дослідження та їх обговорення. У 2016 році до лабораторії мікотоксикології надійшло 35 проб кормів 3 різних областей України. За результатами мікологічних досліджень встановлено, що усі зразки кормів були уражені грибами. 3 них було ізольовано та ідентифіковано до виду 78 штамів мікроміцетів, в тому числі із зерна пшениці - 11, кукурудзи -21 , ячменю - 19 , сої - 1, висівок -8 , вівсу - 6, кормосуміші - 5 і 3 комбікормів - 7 (табл. 1).

\section{Ідентифікація мікроміцетів, виділених 3 кормів}

Таблиияя 1

\begin{tabular}{|c|c|c|c|c|c|c|c|c|}
\hline \multirow{2}{*}{ Рід мікроміцетів } & \multicolumn{9}{|c|}{ Виділено } \\
\cline { 2 - 9 } & \multicolumn{2}{|c|}{ всього } & \multicolumn{2}{c|}{ кормосуміші } & \multicolumn{2}{c|}{ комбікорми } & \multicolumn{2}{c|}{ зернові } \\
\cline { 2 - 9 } & кількість & \% & кількість & \% & кількість & \% & кількість & \% \\
\hline Penicillium & 14 & 18,0 & 1 & 7,1 & 2 & 14,3 & 11 & 78,6 \\
\hline Fusarium & 21 & 26,9 & 2 & 9,5 & 3 & 14,3 & 16 & 76,2 \\
\hline Alternaria & 12 & 15,4 & - & - & - & - & 12 & 100 \\
\hline Aspergillus & 16 & 20,5 & 2 & 12,5 & 2 & 12,5 & 12 & 75 \\
\hline Iнші & 15 & 19,2 & - & - & - & - & 15 & 100 \\
\hline Всього & 78 & 100,0 & 5 & 6,4 & 7 & 8,9 & 66 & 84,6 \\
\hline
\end{tabular}

Результати дослідження показали, що найбільш розповсюдженими у кормах були гриби родів Fusarium - 21 штам (26,9 \%), Aspergillus - 16 штамів (20,5\%), Penicillium - 14 (18,0 \%) та Alternaria - 12 штамів (15,4\%). Всі інші роди грибів у сукупності складали 15 штамів (19,2\%).

Необхідно відмітити, що найбільш ураженими грибами роду Fusarium були зразки кукурудзи та пшениці (76,2%), роду Penicillium - зразки ячменю та комбікормів відповідно 78,6 та 14,3\%. Гриби роду Aspergillus переважали в кількості $75 \%$ - на зернових (ячменю, сої, пшениці). Менший відсоток ураження грибами спостерігали у кормосумішах - (7,1-9,5-12,5\%).

За цей період також було встановлено токсичні властивості до тестмікроорганізму Tetrachimena pyriformis у 78 штамів мікроорганізмів (табл. 2). 
Токсичну дію до тест-мікроорганізму Tetrachimena pyriformis виявлено у 40 штамів мікроміцетів, що складає 52,4 \%, слаботоксичну - у $26(33,2 \%)$ і нетоксичну - у 12 (15,3 \%) відповідно. Найбільше токсичних і слаботоксичних штамів мікроміцетів було виділено 3 пшениці, ячменю та кукурудзи (відповідно 17-27-30 \%).

Таблиия 2

Ступінь токсичності кормів до тест-мікроорганізму Tetrachimena pyriformis

\begin{tabular}{|l|c|c|c|c|c|c|c|}
\hline \multirow{2}{*}{ Вид корму } & \multirow{2}{*}{$\begin{array}{c}\text { Перевірено } \\
\text { шттамів }\end{array}$} & \multicolumn{6}{|c|}{ Токсичність мікроміцетів } \\
\cline { 3 - 8 } & & \multicolumn{2}{|c|}{ токсичні } & \multicolumn{2}{c|}{ слаботоксичні } & \multicolumn{2}{c|}{ нетоксичні } \\
\cline { 3 - 8 } & & кіл-ть & \% & кіл-ть & \% & кіл-ть & \% \\
\hline Пшениця & 11 & 7 & 17,5 & 3 & 11,5 & 1 & 8,3 \\
\hline Кукурудза & 21 & 12 & 30,0 & 6 & 23,1 & 3 & 25,0 \\
\hline Ячмінь & 19 & 11 & 27,5 & $\mathbf{7}$ & 27,0 & 1 & 8,3 \\
\hline Висівки & 8 & 3 & 7,5 & 2 & 7,7 & 3 & 25,0 \\
\hline Соя & 1 & 1 & 2,5 & 5 & -- & -- & - \\
\hline Овес & 6 & 2 & 5,0 & 3 & 11,5 & 1 & 8,3 \\
\hline Кормосуміші & 5 & 2 & 5,0 & 2 & 7,7 & 1 & 8,3 \\
\hline Комбікорми & 7 & 2 & 5,0 & 3 & 11,5 & 2 & 16,8 \\
\hline Всього & 78 & 40 & 52,4 & 26 & 33,2 & 12 & 15,3 \\
\hline
\end{tabular}

При вивченні токсигенного потенціалу найбільш розповсюджених мікроміцетів вивчено токсиногенні властивості 61 штаму мікроміцетів роду Fusarium на середовищі Чапека. Виділено 27 штамів грибів-продуцентів здатних до токсиноутворення (табл. 3).

Таблиця 3

\section{Результати вивчення токсиноутворення фузаріотоксинів}

\begin{tabular}{|c|c|c|c|c|}
\hline \multirow{2}{*}{ № п/ா } & \multirow{2}{*}{ Назва гриба продуцента } & \multirow{2}{*}{ № штаму } & \multicolumn{2}{|c|}{ Токсиноутворення } \\
\hline & & & Токсин & Кількість мкг/кг \\
\hline 1 & 2 & 3 & 4 & 5 \\
\hline 1 & F. verticilloides & 301 & фумонізин & 85,0 \\
\hline 2 & F. moniliforme & 17 & фумонізин & 30,0 \\
\hline 3 & F. moniliforme & 31 & фумонізин & 100,0 \\
\hline 4 & F. moniliforme & 32 & фумонізин & 25,0 \\
\hline 5 & F. moniliforme & 91 & фумонізин & 92,0 \\
\hline 6 & F. moniliforme & 134 & фумонізин & 100,0 \\
\hline 7 & F. moniliforme & 168 & фумонізин & 150,0 \\
\hline 8 & F. moniliforme & 171 & фумонізин & 60,0 \\
\hline 9 & F. moniliforme & 234 & фумонізин & 100,0 \\
\hline 10 & F. moniliforme & 293 & фумонізин & 80,0 \\
\hline 11 & F. moniliforme & 298 & фумонізин & 130,0 \\
\hline 12 & F.graminearum & 11 & зеараленон & 80,0 \\
\hline 13 & F.graminearum & 19 & зеараленон & 100,0 \\
\hline 14 & F.graminearum & 34 & зеараленон & 100,0 \\
\hline 15 & F.graminearum & 131 & зеараленон & 120,0 \\
\hline 16 & F.graminearum & 176 & зеараленон & 80,0 \\
\hline 17 & F.graminearum & 181 & зеараленон & 110,0 \\
\hline
\end{tabular}


(Продовження табл. 3)

\begin{tabular}{|c|c|c|c|c|}
\hline $\mathbf{1}$ & $\mathbf{2}$ & $\mathbf{3}$ & $\mathbf{4}$ & $\mathbf{5}$ \\
\hline 18 & F.graminearum & 182 & зеараленон & 80,0 \\
\hline 19 & F.graminearum & 190 & зеараленон & 90,0 \\
\hline 20 & F.graminearum & 197 & зеараленон & 100,0 \\
\hline 21 & F. sporotrichioides & 191 & Т-2 токсин & 80,0 \\
\hline 22 & F. sporotrichioides & 199 & Т-токсин & 20,0 \\
\hline 23 & F. sporotrichioides & 201 & Т-2 токсин & 80,0 \\
\hline 24 & F. sporotrichioides & 244 & Т-2 токсин & 70,0 \\
\hline 25 & F. sporotrichioides & 277 & Т-2 токсин & 110,0 \\
\hline 26 & F. sporotrichioides & 279 & Т-2 токсин & 120,0 \\
\hline 27 & F. sporotrichioides & 300 & Т-2 токсин & 60,0 \\
\hline
\end{tabular}

При дослідженні токсичних штамів роду Fusarium на здатність до токсиноутворення за допомогою експрес-методу виявлено 7 продуцентів Т-2 токсину (F. sporotrichioides), 9 продуцентів зеараленону (F.graminearum), 11 фумонізинів. Серед 7 активних продуцентів Т-2 токсину, виділено 2 найбільш активних штами № 277 та 279 (F. sporotrichioides), які продукували токсин в кількості 110 та 120 мкг/кг відповідно. Із 9 продуцентів зеараленону, штам № 131 (F.graminearum), продукував токсин в кількості 120 мкг/кг, а також штам № $181-110$ мкг/кг.

В результаті вивчення токсиноутворення фузаріотоксинів можна зробити висновок, що із досліджених 27 зразків, 21 штам продукував відповідний мікотоксин у досить високій кількості (від 80 до 150 мкг/кг).

У результаті проведених досліджень було виявлено 11 активних продуцентів фумонізинів $\mathrm{B}_{1}$, серед них Fusarium moniliforme штам № 168, який продукував токсин в кількості 150 мкг/кг та Fusarium moniliforme штам № 298, який продукував токсин в кількості 130 мкг/кг.

Висновки та перспективи подальших досліджень. Результати проведених досліджень за період 2016 року вказують на те, що всі досліджені корми були забруднені мікотоксинами, а найбільше, зерно кукурудзи, ячменю, пшениці та комбікорми. Аналіз перевірених лабораторією кормів показав, що гриби родів Fusarium, Penicillium, Aspergillus та Alternaria $є$ досить розповсюдженими.

Найбільше грибів роду Fusarium було виділено із зразків ячменю, пшениці та кукурудзи. Серед виділених штамів 52,4 \% були токсичними та $15,3 \%$ - не токсичними.

В результаті досліджень токсичних штамів грибів роду Fusarium було виділено 7 активних продуцентів Т-2 токсину, 11 - фумонізинів та 9 продуцентів зеараленону від 27 досліджених.

Аналіз проведених досліджень вказує на те, що за забрудненням кормів мікотоксинами необхідний постійний контроль. Виявлені фузаріотоксини (Т-2 токсин, зеараленон) і фумонізин $\mathrm{B}_{1}$ - знижують якість кормів та викликають захворювання у тварин і птиці, а також є небезпечними для людини. Перед виготовленням комбікормів та кормових сумішей необхідно постійно досліджувати інгредієнти на ураженість мікроміцетами та мікотоксинами. 


\section{СПИСОК ЛІТЕРАТУРИ}

1. Ображей А.Ф. Дія Т-2 токсину на організм телят в хронічному досліді / А.Ф. Ображей, О.М. Васянович // Наук.вісник НАУ. - Київ.- 2001. - С. 130-132.

2. Зайченко А.М. Микотоксины: прошлое, настоящее, будущее // Микробиол.журнал. - 2003. - Т.65. - № 1-2. - С. 141-146.

3. Аверкиева О.М. Эффективное противодействие фумонизинам в кормах для птицы / О.М. Аверкиева // Тваринництво сьогодні. - № 5. - 2014. - С. 52-54.

4. Рухляда В.В. Фузаріотоксин Т-2 у кормах і його визначення // Вісн. Білоцерків. ДАУ - Біла Церква. - 1998. - Вип. 4. - Ч. 1. - С. 107-113.

5. Методичні вказівки по санітарно-мікологічній оцінці і поліпшенню якості кормів / А.Ф. Ображей, Л.І. Погребняк, О.Ф. Корзуненко та ін. - Київ, 1998. - С. 107.

6. Ойвин И.А. Методика статистической обработки результатов экспериментальных исследований / И.А. Ойвин // Медгиз. - 1960. - С. 87.

7. Даньшина М.С. Атлас токсичных грибов поражающих корма / М.С. Даньшина, Н.С. Даньшин, В.Ф. Тимчук // Кишинев. - 1985. - С. 91.

8. Зеров Д.К. Визначник грибів України / Д.К. Зеров // Вид. «Наукова думка». - 1971. - Т. 3. - С. 693.

9. Саттон Д. Определитель патогенных и условно патогенных грибов / Д. Саттон, А. Фотергилл, М. Ринальди // М.: «Мир». - 2001. - С. 469.

10. Міждержавний стандарт. Зерно фуражне, продукти його переробки, комбікорми. Метод визначення токсичності ДСТУ 3570-97 / ГОСТ 13496. 7- 97. - ЗАТВ.28.02.98p. - № 125, введений в дію 01.07.99 р.

11. Скринінг-метод одночасного виявлення афлатоксину $\mathrm{B}_{1}$, патуліну, стеригматоцистину, Т-2 токсину, зеараленону та вомітоксину в різних кормах. - Затв. Держдепартам. вет. мед. Мін. АПК України 09.04.1996р.

ОПРЕДЕЛЕНИЕ И ИЗУЧЕНИЕ МИКРОМИЦЕТОВ И ИХ СВОЙСТ ПРОДУЦИРОВАТЬ ФУЗАРИОТОКСИНЫ / Васянович О.Н., Рудая М.Е., Янголь Ю.А.

Проведены микотоксикологические исследования 35 проб зерновых кормов, из которых изолировано и идентифицировано 78 штаммов микромицетов. Установлено, что наиболее распространенными были грибы рода Fиsагіит - 26,9\% от всех исследованных проб, Penicillium - $18,0 \%$ и Aspergillus - 20,5\%. Исследования на тест-объекте Tetrachimena pyriformis показали, что 40 штаммов из 78 были токсичныли. В результате изучения токсигенного потенциила наиболее распространенных микромицетов грибов рода Fияаніит было выделено 7 продуцентов T-2 токсина, 9 продуцентов зеараленона и 11 фумонизинов от общего количества исследованных токсических штаммов.

Ключевые слова: микромицеты, зерно, микологические исследования, фузариотоксинь, фумонизиньл.

MICROMYCETES SPECIES IDENTIFICATION AND STUDY OF THEIR ABILITY TO PRODUCE FUSARIOTOXINS / Vasjanovych O.M., Ruda M.E., Jangol Ju.A.

Introduction. Among many toxic environmental factors, more attention is attracted to the metabolites of mold fungi - micotoxin. More than 45 of only trichothecene mycotoxins have been isolated and studied. T-2 toxin is outstands among them because of especially high toxicity and frequency of detection, as it the main etiological factor of fusariotoxicosis of farm animals. Fusariotoxicosis is periodically registered both in our country and abroad.

Another mycotoxin, which in recent years has become widespread in the EU and CIS countries as a result of global warming, is fumonisin B1.Fumonisin B1 is toxic as for liver, kidneys, so for the cardiovascular system of all animal species, causes the pathology of mitosis in the 
affected tissues followed by cell death.

The goal of the work was to conduct micromycetes species identification in grain fodder from different regions of Ukraine and study the distribution of micromycetes capable to produce fumonisins.

Materials and methods. For the study 35 samples of various types of grain forages (wheat, bran, corn, barley, oats, soybeans) and mixed fodder were sampled.

Results of the study and discussion. In fodder samples we detected Fusarium fungi in $26.9 \%$ of samples, Penicillium in $18.0 \%$, and Aspergillus in $20.5 \%$ of samples.

As a result of identification 78 strains of fungi were isolated, and Fusarium was detected in the largest number of samples.

Tetrachymena piriformis test showed that 40 of 78 studied strains were toxic. Within 27 of studied toxic Fusarium strains, 7 ones were producers of T-2 toxin, 9 producers of zearalenone and 11 producers of Fumonisins.

Conclusions and prospects further research. It is established that grain forages are often contaminated with micromycetes: Penicillium, Fusarium, Alternaria and others.

Toxic strains of fungi of the Fusarium genus are active producers of fusarotoxins: zearalenone, T-2 toxin, and fumonisin B1.

Keywords: micromycetes, grain, mycological studies, fusarotoxins, fumonisins.

\section{REFERENCES}

1. Obrazhej, A.F., \& Vasjanovich, O.M. (2001). Dija T-2 toksinu na organizm teljat v hronichnomu doslidi [Effects of T-2 toxin on organism of calves in chronic experiment]. Naukovyj visnyk NAU - Scientific Journal of NAU, 36, 130-132 [in Ukrainian].

2. Zajchenko, A.M. (2003). Mikotoksiny: proshloe, nastojashhee, budushhee [Mycotoxins: past, present, future]. Mikrobiologichnyj zhurnal - Microbiological journal, 65, 1-2, 141-146 [in Russian].

3. Averkieva, O.M. (2014). Jeffektivnoe protivodejstvie fumonizinam v kormah dlja pticy [Effective antidote of fumonisins in the feed for poultry]. Tvarynnyctvo s'ogodni - Animal husbandry today, 5, 52-54 [in Russian].

4. Ruhljada, V.V. (1998). Fuzariotoksin T-2 u kormah i jogo viznachennja [Fusariotoxin T-2 in the feed and its definition]. Visnyk bilocerkivs'kogo DAU - Bulletin of Bilotserkivska SAU, 4, 1, 107-113 [in Ukrainian].

5. Obrazhej, A.F., Pogrebnjak, L.I., \& Korzunenko, O.F. et al. (1998). Metodichni vkazivki po sanitarno-mikologichnij ocinci i polipshennju jakosti kormiv [Methods of determination of sanitary and mycology assessment and improve feed quality]. Guidlines. Kyiv [in Ukrainian].

6. Ojvin, I.A. (1960). Metodika statisticheskoj obrabotki rezul'tatov jeksperimental'nyh issledovanij [Methods of statistical processing of the experimental investigations]. Kyiv: Medgiz [in Russian].

7. Dan'shina, M.S., Dan'shina, N.S., \& Timchuk, V.F. (1985). Atlas toksichnyh gribov porazhajushhih korma [Atlas of toxic fungi affecting fodder]. Kishinev [in Russian].

8. Zerov, D.K. (1971). Viznachnik gribiv Ukraini [Determinant of fungi of Ukraine]. Kyiv: Naukova dumka, 3, 693 [in Ukrainian].

9. Satton, D., Fotergil, A., \& Rinal'di, M. (2001). Determinant of pathogenic and conditionally pathogenic fungy. Mir - World, 5-28 [in Russian].

10. Mizhderzhavnij standart. Zerno furazhne, produkti jogo pererobki, kombikormi. Metod viznachennja toksichnosti [Interstate standard. Fodder and its derived products. The method of determining toxicity]. (1999) HOST 13496.7-97 from 28 th February 1999. Moscow: Standartinform Rossiiskoi Federatsii [in Russian].

11. Skryning-metod odnochasnogo vijavlennja aflatoksynu $B_{1}$, patulinu, sterygmatocystynu, $\mathrm{T}-2$ toksynu, zearalenonu ta vomitoksinu $\mathrm{v}$ riznyh kormah. [Screening method for the detection of aflatoxins $B_{1}$, patulin, sterigmatocystin, T-2 toxin, zearalenone and vomitoksin in feeds]. (1996). Kyiv: Min. APK Ukrai'ny [in Ukrainian]. 